\title{
HUMAN DIGNITY AND CHURCH RE-UNIFICATION IN THE FAMILY OF DUTCH REFORMED CHURCHES
}

\author{
Sipho Mahokoto \\ Systematic Theology \\ Stellenbosch University
}

\begin{abstract}
In this article church re-unification is developed as an instrument that can contribute to the restoration and better understanding of violated human dignity The argument is based on three central concepts used by the World Council of Churches in its debates on church unity, namely 'costly unity', 'costly commitment' and 'costly obedience'. It is argued that both human dignity and church unity are costly as it cannot be earned, but should be realized in relationship with God and fellow human beings.
\end{abstract}

Key Words: Church Unity, World Council of Churches, Ecumenical Movement, Ubuntu, Dutch Reformed Churches

\section{Introduction: Church Unity Debate in South Africa}

The church unity debate in South Africa among the member churches of the Dutch Reformed Church (DRC) family has become extremely important. Among other things, it became important because church unity aims to bring people together irrespective of their cultural backgrounds, with a view to recognising one another as humans, as creatures of God who bear his image and as members of the same body of Christ. The events in South African history that perpetuated division, not only among the church members of the DRC family, but also among all South Africans and the denial of human dignity of some, resulted in this debate of church unity. It has also led to the restoration of the dignity of those whose dignity had been violated for decades. One of the biggest events in the history of the DRC family was the decision of the synod of 1857 that occurred after white church members refused to partake of Holy Communion with non-white congregants. The synod decided to provide separate church buildings and church services for non-white congregants. Many events in South African history have damaged, dehumanised or even violated the human dignity of others, especially black people. This leaves us with the challenge of how our society can be renewed, and also how human dignity that was violated in many respects, can be restored. Recently, xenophobic attacks became an issue that attracted the attention of the global community, especially as they were carried out by black people against fellow blacks. But a number of questions arise from this: What is the church supposed to do in these situations? What voice comes from the church in order to protect, to care and restore human dignity that is violated every day and hour in our young democratic South Africa? How does church unity challenge us to appreciate and to love one another as humans who have the same and equal dignity, irrespective of our racial differences? In what ways can church unity really challenge us to care, to protect, to respect and to celebrate our unity in diversity? 
Many church leaders in South Africa, such as Archbishop Mpilo Tutu, Allan Boesak, Frank Chikane, and Beyers Naudé, to mention but a few, have played a remarkable role in the history of South Africa in protesting against the violation of human dignity of many South Africans. They tried to reshape and renew South African society so that all people of different races would learn to respect, care and understand one another as nothing less or more than a creation of God who bears his image. For these leaders and many others, human dignity and the unity of the church, play a critical role in the renewal of society. The church played a remarkable role in condemning division and the violation of human dignity. This leads me to look at how the World Council of Churches (WCC) strives to help us understand the importance of church unity for the renewal of society.

\section{The World Council of Churches and Church Unity}

An important church debate dealing with the question of the social significance of church unity is the ecclesiological and ethics debate of the WCC. The unity discussions in the Faith and Order section showed that unity cannot be separated from social ethical discussions in the Life and Work section. However, it is argued that during the process which led to the formation of the WCC in 1948, the Faith and Order movement played a fundamental role in discussing the ecclesiological meaning of unity, as well as the ecclesiological significance of the WCC.

Peter Lodberg argues that the fathers of Faith and Order tried to maintain the balance between the quest for a theological understanding of church unity, and the real, existing disunity among confessional churches, by implementing a double strategy. The double strategy that was used, on the one hand stressed the importance of a pre-existing hidden una sancta in the visible separated churches. On the other hand, the strategy wanted to formulate a consensus of how the ideal of church unity might be realized in the world (Lodberg, 1995). In other words, the strategy wished to find a way of how the church could be public and make its unity visible to the world. What role can church unity play in the world? What is the significance of church unity to a broken society and a broken people whose dignity had not been recognised for years? What are the ethical implications of church unity with regard to the human dignity debate?

A reflection was made that the Faith and Order movement must not only focus on itself, but should also face the world and its challenges with a solidarity that serves. However, one of the speakers at the world conference exerted pressure on the participants as well as the churches to understand the search for ecclesial reconciliation within the context of the world's divisions and the struggle for justice and hope (see Crow, 1993). Crow (1993) states that baptism is not only the sacrament of church unity, but the sacrament of unity and reconciliation of all persons and all creation in the life of God.

At the Uppsala Conference of Faith and Order in 1968, it was discussed that the church is sent into the world by the Holy Spirit, whereby it becomes what it is intended to be, a renewed and renewing community. Not only is the world renewed, but also the church itself. Lodberg argues convincingly that unity within the church is established by working for unity in the world outside the church. In the same way the work for unity in the world will influence the life of the church. However, Uppsala recommended that more work must be done on the relationship between the unity of the church and the unity of mankind (Lodberg, 1995). The churches must work closer with those victims in serving justice and reconciliation for societal renewal. Social action is now understood to be an authentic part 
of the mission (Missio Dei) of the church. In most of these consultations, the main aim was to find a way of combining the Faith and Order tradition and Life and Work tradition.

Dirkie Smit (2003) in his article entitled Living Unity? On the ecumenical movement and globalisation gives an outline of the work of the Ecumenical Movement in bringing the Faith and Order section, and Life and Work section together as Ecclesiology and Ethics under the vision of koinonia. The major concern was the work of the church in the world as a social ethic, a koinonia ethic. Smit argues that the focus of Faith and Order (Ecclesiology) has been on the visible unity of churches in the world, both globally and locally.

There have been a lot of shifts in thinking regarding the nature of this unity. However, several descriptions have contradicted one another. Smit argues further that, Faith and Order always understood that the efforts towards achieving the unity of the church and efforts towards a common witness and service in the world should be held together (see Smit, 2003). Smit points to the work on Unity of the church and the unity of humankind and The community of women and men in the church as a reflection of these efforts. The ongoing discussion resulted in a study programme called The unity of the church and the renewal of human community.

Smit (2003) points out that the purpose of the Church and World reflections is therefore to affirm and explore this inter-relation of two fundamental ecumenical tasks: the search for the visible unity of Christ's church, which is very costly, and the search for a common Christian proclamation, witness and service as expressions of God's mission and love for a world crying out for renewal. He states that Christians and churches live in this world and share in its anxieties and hopes (Smit 2003). Called to become what it is, the church knows that this striving is not for the sake of the church alone, but it is in and for the world that God calls the church. The task of the church, as well as its identity, is understood from the point of view of God's Kingdom, as both mystery and prophetic sign. Lodberg is also of the opinion that the task of the church is that of interpreter, identifying the signs pointing towards the kingdom of God, and to take an active part in the realization of the signs.

However, ecclesial unity is sometimes regarded as necessary for practical reasons, to make the collective endeavours of the church stronger, in the face of the social, political, and economic challenges they are facing. Smit argues that the interest in visible unity is functional and practical. In this regard, the main focus is ethical rather than ecclesiological. In other words, the focus is on the social implications of church unity, serving justice in society.

At the 1990 Seoul meeting of Life and Work, all the member churches were engaged in a conciliar process of mutual commitment to justice, peace, and the integrity of creation. The Seoul convocation tried to maintain the interconnection between ethics and ecclesiology in its final message, by introducing the concept of kairos, showing the emergence of certain ethical challenges to the churches. Lodberg underscores that it is in the daily conflicts of human life that the unity of the churches is tested, and it is the way the churches deal with the social, political and economic conflicts shows the quality of the conciliar fellowship in the church. More importantly, Lodberg argues that the church, as a reconciled community in Christ, must bring its members closer together in a common recognition of baptism, eucharist and ministry. He further argues that this would help the church to become and be a trustworthy instrument of reconciliation in the world (Lodberg, 1995). However, in doing this, the church would also help society to be an instrument of justice and reconciliation. This would contribute to the renewal of the human community, where we could move from division to unity, from enmity to reconciliation, and from alienation to justice. 
Susan Moore argues that in the writings of the New Testament, the concept of koinonia expressed ideas that were close to the heart of the early Christian's common life. She states that later theology took up the word to express the loving communion, the unity in diversity, of the persons of the Trinity, and it also depicted the church as a fellowship that echoes God's koinonia (Moore, 1995). She explains that koinonia carries a wide range of meanings: community, communion, sharing, fellowship, participation, partnership, solidarity, it also denotes spiritual relationship, and sharing worldly goods. In her argument, Moore states clearly that in this koinonia, within God's loving communion, diversity is held together without separation, while at the same time unity is enriched by diversity. She states that, if the church echoes koinonia, then unity and diversity belong together in the church (Moore, 1995).

Daniel Louw also views koinonia as an important aspect and tool that the church can utilise for unity. In his words, Louw argues: "The so-called unity of the church is an expression of faith. It professes a faith in a God whose vulnerability opens up new avenues for human beings to rediscover their human dignity. Co-existence as koinonia is based upon the ethics of sacrificial and unconditional love" (Louw, 2003:58). Hence, Louw argues that unity should be sought in order to safeguard human dignity and to care for people.

The same notion of koinonia played a remarkable role in the proceedings of the World Conference of Faith and Order in Santiago de Compostella in 1993 where the picture of visible unity was developed. However, the relation between the church and the wider human community became a new and thoroughgoing perspective for the reflection on the unity of the church. In this conference, according to Smit, koinonia with three sub-themes was discussed, namely koinonia in faith, in life, and in witness. An official report of the conference entitled: On the way to fuller Koinonia was published (Smit, 2003). One of Santiago's aims was to help churches to relate the search for unity to their call to be effective signs of God's purpose for humanity and creation. That is why each local Christian community is called to a unity that consists of absolute interdependence (1 Cor $12: 21)$. No member of the same body can reject another, they need one another, and they depend on one another. Such unity will help the members of the church and members of the community to become closer and become aware of the need for interdependence, sharing, and communion with one another.

Margaret Jenkins argues that the Faith and Order document, Baptism, Eucharist and Ministry (the Lima document), together with the responses to it from many churches, give evidence of an important and widely affirmed ecumenical advance. Reflecting on the concept of koinonia, the communion to which we are called, she argues that, "because this communion embraces the whole of our existence, we cannot reflect on the specific concerns of sharing a common life in Christ in isolation from koinonia in faith and witness" (Jenkins, 1993, p. 93). Her point of departure is that the sacraments and service are expressions of the same faith which we share and actualize in our Christian witness to the world. These discussions led to three consultations, namely 'Costly Unity,' 'Costly Commitment,' and 'Costly Obedience.'

\section{Costly Unity}

Costly Unity is the first report of a meeting in Rønde, Denmark, in 1993 where it was proposed that the church should be viewed as a moral community (Smit, 2003). On the one hand it was argued that, 'cheap unity' avoids morally contested issues, because such issues would disturb church unity. However, on the other hand, 'costly unity' in the church as a 
moral community, reveals the unity of the churches to be a gift as a result of pursuing justice and peace. The churches should promote justice, peace and the integrity of creation. William Henn is of the opinion that 'costly unity' attempts to draw lines of continuity between the nature of the church and the church's advocacy role for justice, peace and the integrity of creation. This led to a general impression that the 'costly unity' study relates to ecclesiology and ethics (Henn, 1995). ${ }^{1}$

Forrester (1997b) underscores that, just like grace, 'costly unity' is a precious gift, which requires a costly response. Nevertheless, it has been gained for us by Jesus and we need to show its reality in a world that is still full of division, conflict, suspicion, hostility, racism, xenophobia, rape of young children and women and many other forms of injustice that prevent people from recognising their interconnectedness. However, it is clear that the kind of church unification that is needed is that which will have an impact on societal renewal and in the restoration of human dignity, and which carries reconciliation and justice as instruments for renewing the church itself, as well as society.

According to Forrester, we need to live out the unity and shalom that Christ has won (Forrester, 1997b). He asserts that unity cannot be had without taking risks. The life of faith is a life of risk-taking. Since church unity is costly, the church's task is to play the role of discipleship. This is also true with regard to the fight against the violation of human dignity during the struggle in South Africa.

'Costly unity' is the discovery of the churches unity in struggles for peace and justice. 'Costly unity' can come only when the real sources of conflict, distrust, injustice, violence, apartheid, and old grievances, which constantly refresh bitterness, are addressed and wrestled with and gradually healed at their source. The same sources need to be addressed within the ranks of the DRC Family. This unity, by God's grace, breaks down dividing walls so that we might be reconciled to God and to one another. This 'costly unity' drastically changes and renews the church and society through reconciliation and justice. The focus is to bring about unity in the church and in society where reconciliation and justice will prevail. This is not easy for the church and for anyone, it is costly.

\section{Costly Commitment}

Costly Commitment was the second report of the meeting at the Tantur Ecumenical Institute in Jerusalem. Smit explains that this meeting discussed the issue of the church as a moral community. The calling and vocation of the church was emphasised here. The churches, Smit argues, even as moral communities are called to commit themselves to one another, recognising that they need each other on their ecumenical journey. For him, such commitment to one another is an important aspect for their common reflection and action (Smit, 2003). ${ }^{2}$ It becomes increasingly clear that the road to a 'costly unity' leads necessarily through a 'costly commitment' of the churches to one another. The relationship between ecclesiology and ethics was explored and the fundamental vocation of the church and of Christians who work together in facing crucial issues of this time. The churches recommitted themselves to work for justice, peace and greater integrity with regards to

\footnotetext{
Henn argues that in terms of ecclesiology and ethics, or koinonia and ethics, these two terms are referring to engagement on behalf of justice, peace and the integrity of creation.

2 Smit highlights the fact that the road to 'costly unity' leads necessarily to a 'costly commitment' of the churches to one another. Those churches who have previously been wary of moral reductionism should now commit themselves to the ethical character of the church. Those who have been deeply involved in ethical praxis only, should commit themselves also to ecclesial renewal.
} 
creation. This links more closely the search for a sacramental communion of the church with its struggles for peace and justice.

Forrester asserts that the continuing divisions on important matters of faith, order, life and work have often prevented the churches from offering a unified witness on crucial ethical issues. However, he argues that the divisions among churches reveal the brokenness of their koinonia, and hamper their prophetic mission and service in the world (Forrester, 1997b). The divisions amongst the churches will not have any impact on societal renewal, but will rather cause more harm to society and creation. The churches will only have an impact on society if the churches are united and committed to one another in addressing the ethical issues that confront society. 'Costly commitment' addresses the commitment that the church should have in the world, in its dealing with justice and reconciliation. That step towards church unity makes things easier for the church in its dealings with societal renewal and indeed its own renewal.

\section{Costly Obedience}

The Costly Obedience meeting was held in Johannesburg in 1996. The theme of moral formation was addressed, leading with the following question: What might it mean to speak of the church as a global communion of moral witnessing? In attempting to answer this question, it was discovered that the obedience to which the church is called, is often very costly. Smit argues that it may require the churches to position themselves in relation to the issues of particular times and places, in ways which necessitate courageous perseverance and sacrifice. Such faithfulness may even come to the point of martyrdom (Smit, 2003). In summarising the meetings, Smit points out clearly that the koinonia to which the oikoumene (household) is called, which involves communion in faith, in life, and in witness, takes the form of 'costly unity' - which means that faith involves discipleship - and calls the churches to a 'costly commitment' to one another, as well as to 'costly obedience', facing the struggles of life for every age (Smit, 2003).

As Christians, we speak of an oikoumene, offered by God in Jesus Christ to the human race. This is called the household of life where justice, peace and the care of creation prevails. The challenges concerning living unity and real reconciliation remain as urgent as the challenge of striving for justice. Smit argues that one cannot aim for unity without working for reconciliation; also, one cannot expect reconciliation to happen without justice (Smit, 2003). It is the church, in its endeavours for church unity that will bring about reconciliation and justice. Our societies will never be renewed without the church taking the initiative to address ethical challenges such as HIV/AIDS, poverty, alienation, enmity, corruption, human dignity violation, rape, women and child abuse, as well as many other injustices in our society. The aim of church unity is to renew the church itself, bringing reconciliation and justice into practice daily, and also renewing society. This will only be achieved by showing commitment, by obediently seeking a costly and visible unity for the renewal of society. That unity must enhance the work of reconciliation and social justice in society.

Forrester (1997a) argues that the mission of the church and its calling is not for its own sake, but for the sake of the world and the welfare of the broader community. He argues that the church, as koinonia, is called to share not only in the suffering of its own community, but in the suffering of all. This is achieved through advocacy and care for the poor, the needy and the marginalized, by joining in all efforts for justice and peace within 
human societies. It is also brought about by exercising and promoting the responsible stewardship of creation and by keeping alive hope in the heart of humanity.

\section{Human Dignity is Costly}

Human dignity is costly simply because it is not our own, we do not earn it, we do not create it. It is given by God's grace. God created us in his own image; we are like him, male and female. In the Heidelberg Catechism, it is clearly stated that we do not belong to ourselves, but to God who created us, who loves us, who appreciates us as his creation. We are God's children; we belong to him only, not to anyone else. That is why the dignity given to us by God should not be violated, because we do not own ourselves. Since we belong to this God who made us, we automatically belong to one another as children of the same household. Since we belong in the same household of the Father, our dignity is equal and flows from the Father. In a sense, we should protect one another as the Father protects us. Anything that we do against the other in order to violate another's dignity, we do that against God the Father. We do not own one another. The dignity given to us by God is very costly. We do not have the right to disrespect, oppress or even violate another person's dignity.

In conclusion, the concept of human dignity and church unity is important in Africa today simply because it constantly reminds us that we belong to one another. It always reminds us that my dignity is equal to the other person's dignity. The question of human dignity in Africa today keeps on challenging us to practice what ubuntu and koinonia implies to people, not only to Africans, but to the whole world. When saying umntu (a human) in Xhosa, then everyone knows that you are talking about a human whose dignity is God-given. People know that you need to respect umntu even if that human is lying there as a corpse. However, we come from the same human race and therefore belong to each other. We are the members of the same body of Christ and he is the head. Anything that hurts the dignity of the other affects my dignity. During the apartheid struggle, the South African Communist Party (SACP) had a motto that said: 'An injury to one is an injury to all.' This is exactly the meaning of the notion of the body of Christ, but from a political perspective perhaps the politicians never realised it. All the members of the body suffer together, carry the same pain, cry together, rejoice and also work together to carry the pain experienced by one member of the body. It is impossible to realise who you are until you see others around you, recognise them, and appreciate them, and share their pain, suffering and joy, when life goes smoothly. The notion of the body of Christ challenges us to see one another through the eyes of Christ. In this sense, we realise that we belong to One Body and that we are members of the same household, my dignity is equal to the dignity of others.

The notion of the body of Christ helps us to acknowledge that we are weaker without other human beings around us. The only hope for the renewal of society and the restoration of our dignity, as people, is to realise that we belong to one another. We should constantly keep in mind that the unity to which God has called us is very costly. This unity is expressed in the notion of the body of Christ, and that we really need to commit ourselves to one another, acknowledging one another and our diversity. We should strive to look at the other through the eyes of Christ. The obedience that we give to God must also serve as obedience to one another. And finally, our dignity is costly, we do not earn it, we do not create it, but it comes from God, and therefore we should handle it with great respect. 


\section{BIBLIOGRAPHY}

Crow, PA 1993. The Legacy of Four World Conferences on Faith and Order. Ecumenical Review, 45 (1), January.

Forrester, Duncan 1997a. Ecumenical Ethical Engagement, Moral Formation and the Nature of the Church. In T Best \& R Martin (eds.). Ecclesiology and Ethics. Geneva: WCC Publications.

Forrester, D 1997b. The True Church and Morality: Reflections on Ecclesiology and Ethics. Geneva: WCC Publications.

Henn, W 1995. Reactions and responses... to costly unity and to the discussion in Santiago: A Roman Catholic perspective. Ecumenical Review, 47(2), April.

Jenkins, M 1993. Towards koinonia in life. Ecumenical Review, 45(1), January.

Lodberg, P 1995. The history of ecumenical work on the ecclesiology and ethics. Ecumenical review, 47(2), April.

Lodberg, P 1995. The History of Ecumenical Work on the Ecclesiology and Ethics. Ecumenical review, 47(2), April, 128-129.

Louw, DJ 2003. The unity of the rainbow versus the diversity of cultures? In E van der Borght (ed.), Affirming and living with differences. Zoetermeer: Meinema.

Moore, S 1995. Towards koinonia in Faith, Life and Witness. Ecumenical review, 47(1), 3-11.

Smit, DJ 2003. Living Unity? On the ecumenical movement and globalisation. Scriptura, 84, 423-437. 